\title{
The Entrepreneurial Learning Process And Influential Factors of Entrepreneurs in Business Model Construction
}

\author{
Ke Zheng \\ Management School \\ Sichuan Agricultural University \\ Chengdu, China \\ Zhengkeke390@163.com
}

\begin{abstract}
Build a theory model of Entrepreneurial learning based on business model theory. The model comprises three phases including value proposition, transactional institution implementation and strategic planning. Case study shows that the leading learning process in value proposition phase are observation and innovation, well in transactional institution construction phase are contextual negotiation and learn by doing, in strategic planning phase are profound cognition and innovation. Empirical study shows that the effects and experiencing degree of Entrepreneurial learning in business model construction are positively influenced by Entrepreneurial idiosyncrasies which are measured by identification as entrepreneurs, social network building ability and creative thinking habits.
\end{abstract}

Keywords- Business model; Entrepreneurial learning

\section{INTRODUCTION}

Entrepreneurial learning emerged as a promising research area combined with learning theory and Entrepreneurial context, which typically regards Entrepreneurship as a learning process (Minnit\&Bygrave,2001; Wang\&Chugh, 2014).Usually, researches in EL are focusing on the opportunity identification and exploration process. EL was seen as the working mechanism of how Entrepreneurs acquire and transform information into Entrepreneurial knowledge that helped in opportunity pursuing (Corbett, 2005). Well in answering how and what do Entrepreneurs learn, many conceptual models are developed. Many of those models follow the theories of experience learning and cognition, especially the work of Kolb. Kolb (1984) defines learning as a process of experiences transformation, and distinguishes four types of knowledge forming, namely convergent, assimilative, divergent and accommodative. As concluded by Corbett(2005), "When an individual grasps experience through apprehension and transforms through intention, he or she creates divergent knowledge. Experience grasped through comprehension and transformed through intention creates assimilative knowledge. When an individual grasps through comprehension and transforms through extension, he or she creates convergent knowledge. Lastly, when one grasps experience through apprehension and transforms it through extension, accommodative knowledge results."

Corbett(2005)use Kolb's definition to rebuild the Creativity-Based Model of Opportunity Recognition first proposed by Lumpkin\& Lichtenstein(2005). In this new model, convergent, assimilative, divergent and accommodative learning respectively matched the creative stages of Opportunity Recognition which were preparation, incubation, evaluation and elaboration. Politis(2005)also follows the experiences transformation view from Kolb, but highlights the distinction between entrepreneurial experience gained form directly participates in entrepreneurial events and the entrepreneurial knowledge derived from those experiences. As to the working mechanism of this transformation process, Politis(2005)employs March’s(1991)theory of Exploration and exploitation in organizational learning. Exploitation concerns the exploitation of what is already known, including "such things as refinement, routine, and implementation of knowledge", while Exploitation means to "explore new possibilities including issues such as variation, experimentation, discovery, and innovation”(Politis, 2005). Because of the complexity cognition process in Entrepreneurial learning, heuristics or Intuitive draws the attention of many scholars. Holcomb elt. (2009) highlights the influence of heuristics to the major two Paths of Entrepreneurial Learning which are Experiential Learning and Vicarious Learning.

In comparison to the cognition research perspective emphasizing psychology and thinking aspects of EL, there is another perspective focusing on the behavioral process of EL. Cope(2000,2005,2007, 2011) regards EL itself as a process in behaviors, and gradually formed a complete model of EL focusing on entrepreneurial behaviors. In Cope's model, "Learning by doing" and "Learning through crises" are the two paths of behavioral learning process in Entrepreneurship. "Learning by doing" means to learn from Trial and error, problem solving and discovery; "Learning through crises" means to earn from a series of disperse crises occurred during Entrepreneurship. The fact that EL cannot be abstract form the behavioral process also means that EL cannot be abstract form the entrepreneurial context in which behaviors happened. Rae(2006) construct a triadic model of entrepreneurial learning centered on three major themes including Personal and social emergence, Contextual learning and Negotiated enterprise. The case study indicates that the development of entrepreneurial identity is the outcome of personal and social emergence, and the learning about opportunity recognition is conducting in the context of specific industry, community and related networks. Negotiated enterprise refers to the fact that in order to do business venture, entrepreneurs have to negotiate with inner 
stakeholders on the meaning, structures and practices of enterprise, as well as build engagement in networks of external relationships. So the contextual negotiation is the learning itself.

Compared to the plenty researches of EL form the perspective of opportunity identification and exploration process, there is little attention given to the business model construction process of new enterprise. Business model theory is newly built to explain the fast growing IT-based enterprises with innovative way of doing business. Earlier researchers Mitchell\&coles(2004) defined BM as "the combination of who, when, where why, how and how much an organization uses to provide its goods and services and develop resources to its continues efforts". "The business model is seen as a tool for depicting, innovating and evaluating business logics in startups and in existing organizations (Veit,elt.,2014)". Business logics can be simply explained as how and why an enterprise can make profit out of what it's doing given the business network it has been planted in. In the famous work of Osterwalder\&Pigneur(2011), business model is defined as the basic principal for an enterprise to create value, transfer value and gain value. They construct a widely used model for creating and adjusting business model called the canvas theory which centered value proposition. Different from value creation point of view in business model research, another perspective is focusing on the transaction structure. Wei \& Zhu (2012) see business model as a transactional structure of stakeholders with independent interest demands. So form the perspective of BM, EL can be seen as how entrepreneurs come up with certain value proposition, and how do they construct a transaction structure for their value proposition to be delivered.

\section{THEORY AND CASES}

\section{A. The model}

When discuss EL based on business model construction, the main task and goals of EL specifically become a consecutive staged process which includes value proposition, transaction institution construction and strategic planning. Value proposition as the first stage of EL is very much coherent with opportunity recognition, but is mainly idea forming without any actual behaviors delivered. The realization of value proposition is through the construction of transactional institution, which is depending on the negotiation activities between entrepreneurs with stakeholders. Strategic planning as an advanced learning stage is developing based on value logics and transactional rules from earlier learning stages. Figure 1 represents the theoretical process of EL based on business model construction perspective.

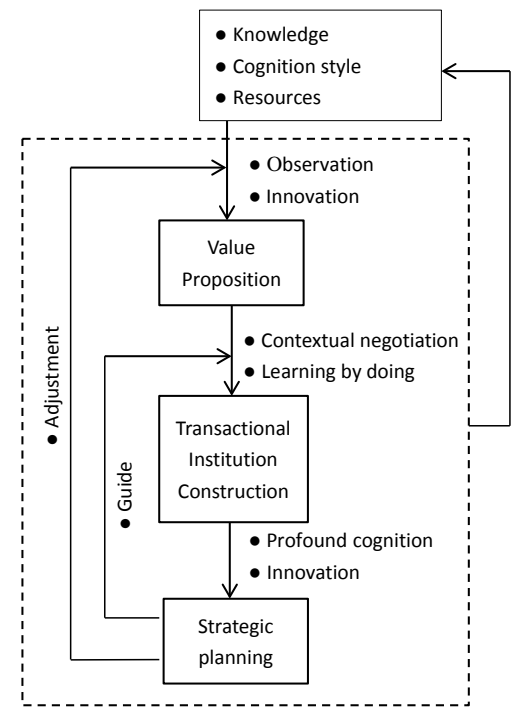

Figure 1

Concept model of Entrepreneurial learning process in business model construction

In this model, three EL phases are clearly divided, and the leading learning modes of each phase are represented, as well as the inner connection within those phases. In value proposition phase, the leading learning modes are observation and innovation, which is coherent with the fact that entrepreneurs are usually recognize potential value through directed contacts, observation to certain trends or phenomenon, as well as creative connections. The sudden happenings of these observation and creative connections are largely influenced by former knowledge, cognition style and the available resources, which have already been mentioned in some earlier researches(Shane \& Venkataraman, 2000;Politis, 2005). The entity of business model is series of concrete transactional Institutions bounded by economic, behavioral and social regulations, which means the entrepreneur has to understand and make use of those regulations to design his business model to realize his business ideal. And those regulations can only be mastered through specific tasks accomplishing within concrete entrepreneurial context, which means that the leading learning modes in this phase should be contextual negotiation and lean by doing. Strategic planning in this model refers to the advanced conceptual work of entrepreneurs to understand and make use of the predictability of business model in order to plan a greater value space for the business. So the leading learning modes in this phase would be profound conceptual work as well as innovation. The results of Strategic planning may cause the adjustment of value proposition or guide the rebuild of transactional Institutions. The complete of the whole EL process would finally become the former Knowledge of entrepreneurs and influence the formation of cognition style and the available resources. 


\section{B. Case Study}

I choose 5 entrepreneurs different in personal background and in business areas to do in-depth case study on their EL process during the business model construction. The simplified background descriptions of these 5 cases are presented below.

Table 1 Descriptions of cases background

\begin{tabular}{|c|c|c|c|}
\hline No. & Projects & $\begin{array}{c}\text { Entrepreneurs' } \\
\text { background }\end{array}$ & $\begin{array}{c}\text { Entrepreneurial } \\
\text { phase }\end{array}$ \\
\hline 1 & $\begin{array}{c}\text { GIS } \\
\text { development for } \\
\text { rural land rights } \\
\text { registration }\end{array}$ & $\begin{array}{l}\text { Professor, the } \\
\text { director of GIS } \\
\text { research center of } \\
\text { college }\end{array}$ & $\begin{array}{c}\text { Fast growing phase } \\
\text { with constant } \\
\text { business model } \\
\text { adjustment }\end{array}$ \\
\hline 2 & $\begin{array}{l}\text { Sounding } \\
\text { Equipment } \\
\text { Rental Services }\end{array}$ & $\begin{array}{c}\text { Graduate, have } \\
\text { plenty Corporate } \\
\text { practice experiences }\end{array}$ & $\begin{array}{l}\text { Fast growing phase in } \\
\text { early operation stage } \\
\text { of business model }\end{array}$ \\
\hline 3 & $\begin{array}{c}\text { e-commerce } \\
\text { Web site for } \\
\text { qualified goods }\end{array}$ & $\begin{array}{l}\text { Graduate, gain many } \\
\text { support from family }\end{array}$ & $\begin{array}{l}\text { In the negotiation } \\
\text { phase of business } \\
\text { model construction }\end{array}$ \\
\hline 4 & $\begin{array}{l}\text { Cultivation and } \\
\text { selling of } \\
\text { aquiculture }\end{array}$ & $\begin{array}{l}\text { Aged laid-off } \\
\text { workers with little } \\
\text { resources could } \\
\text { support their } \\
\text { business }\end{array}$ & Marketing phase \\
\hline 5 & $\begin{array}{c}\text { property } \\
\text { management for } \\
\text { communities }\end{array}$ & $\begin{array}{c}\text { Former worker in } \\
\text { property } \\
\text { management } \\
\text { company }\end{array}$ & $\begin{array}{c}\text { Stabilization period } \\
\text { with a mature } \\
\text { business model }\end{array}$ \\
\hline
\end{tabular}

Case study shows that, in value proportion phase, entrepreneurs seldom make sophisticated consideration. In stand, they usually sense the potential value through direct or indirect contacts with the potential needs or through paying close attention to certain trend which are usually associated with experiences or interests. This kind of "occasional discovery" has much to do with their constant observation and timely innovative thoughts. In transactional institution construction phase, entrepreneurs begin to make contacts with potential dealers of resources and stakeholders through network expanding. By consulting, imitating and negotiating with network members, entrepreneurs gradually have insights about those rules they about to follow. The trial and error and constant behavioral adjustment are throughout the process of specific tasks conducting. Strategic planning in those cases are usually begin to happen in their deep insights about the industry and market trends, and the clear understanding about the differences between their projects and the existing competitors. Above those understands, entrepreneurs begin to draw a big but clear picture about where they are going and how.

Based on the case study, I put forward a theoretical framework of the EL process in the construction process of business model, which is showed in Table 2.
Table 2 EL Process in The Construction Process of Business Model

\begin{tabular}{|c|c|c|c|}
\hline EL objects & EL tasks & EL Mechanism & Show in Case \\
\hline $\begin{array}{l}\text { transactional } \\
\text { institution } \\
\text { construction }\end{array}$ & $\begin{array}{l}\text { Recognize } \\
\text { the } \\
\text { differences; } \\
\text { predict the } \\
\text { trends; make } \\
\text { innovative } \\
\text { plan }\end{array}$ & $\begin{array}{l}\text { EL material: former } \\
\text { knowledge, direct } \\
\text { and indirect } \\
\text { experiences } \\
\text { EL path: Profound } \\
\text { cognition, } \\
\text { Innovation } \\
\text { Cognition model: } \\
\text { divergent, sense, } \\
\text { intuitive, exploration }\end{array}$ & $\begin{array}{l}\text { Sensitive to } \\
\text { certain needs due } \\
\text { to former work } \\
\text { experiences or } \\
\text { technical } \\
\text { background; } \\
\text { sense to trends; } \\
\text { give constant } \\
\text { attention to } \\
\text { certain } \\
\text { phenomenon } \\
\text { Make contacts } \\
\text { with potential } \\
\text { dealers and } \\
\text { stakeholders } \\
\text { through network } \\
\text { expanding; } \\
\text { negotiate based } \\
\text { on mutual } \\
\text { interest; pursue } \\
\text { and create new } \\
\text { way of } \\
\text { cooperation } \\
\text { Have insights } \\
\text { about the rules } \\
\text { and trends of the } \\
\text { industry; } \\
\text { understand the } \\
\text { advantage and } \\
\text { disadvantage of } \\
\text { their business; } \\
\text { knowing the } \\
\text { difference with } \\
\text { their } \\
\text { competitors; } \\
\text { create new way } \\
\text { of doing business }\end{array}$ \\
\hline
\end{tabular}

\section{EMPIRICAL TEST FOR INFLUENTIAL FACTORS}

\section{A. Factors}

What factors have important influential effects in EL during the construction of business model? Former researchers already highlight the knowledge and recognition style has much to do with opportunity recognition. And according to the study of Rae (2006)'s opinion on identification emergence and contextual negotiation, the willingness to psychologically identified as entrepreneurs and the ability in social network building may also positively influence the EL. So in this study, combined the theoretical opinion and the case study, I focus on three potential influential factor which are entrepreneurial idiosyncrasy, available resources and level of experience. Here the entrepreneurial idiosyncrasy is consisting three dimension including identification as entrepreneurs, social network building ability and creative thinking habits. Than we have the following hypothesis:

(1)H1: The more entrepreneurial idiosyncrasy an entrepreneur shows, the better effects of EL in accumulating the knowledge of business model. 
(2)H2: The more entrepreneurial idiosyncrasy an entrepreneur shows, the greater experiencing degree of EL in business model construction.

\section{B. Questionnaire}

Six simple questions are designed for entrepreneurial idiosyncrasy as bellow:

(1)Identification as entrepreneurs: a. I have a strong desire to be an entrepreneur; b. I mentally identified with my status as an entrepreneur.

(2)Social network building ability: a. I am able to make contacts with some critical persons; B. I am able to become a member of the critical social circles.

(3)Creative thinking habits: a. I always diligent in thinking the problems I met in entrepreneurship; b: I always have my unique opinion or ideas.

Six simple questions are designed for the effects of EL in accumulating the knowledge of business model as bellow:

a. I totally understand the current situation and future trends of the market;

b. I have a clear plan for future development;

c. I know clearly about the advantage and the disadvantage of my business;

d. I have a clear understanding of the competitor's behaviors;

e. I very much understand the interest demand of my stakeholders;

f. I know clearly about the needs of my customers.

Three questions are designed for the experiencing degree of EL in business model construction:

a. I formed many fresh opinions in entrepreneurship;

b.I have experienced a great change in entrepreneurship;

c. I update many old opinions in entrepreneurship.

\section{Sample and test}

The final sample is 70 young student entrepreneurs during the age of 18 to 30 , of which $61.43 \%$ were male and $38.57 \%$ were female. $72.86 \%$ have bachelor's degree, $8.67 \%$ have degree that is above bachelor. $28.57 \%$ plays the leading role in team.

I use tow simple expressions to testify the tow HYs: (1) knowledge results $=\mathrm{B} 1$ entrepreneurial idiosyncrasy+B2Control Variables $+\varepsilon$; (2) experiencing degree $=$ B1 entrepreneurial idiosyncrasy+B2 Control Variables $+\varepsilon$. The Regression results are expressed in Table 5.
Table 5 The Regression results for HYs

\begin{tabular}{|c|c|c|}
\hline Variables & M1 & M2 \\
\hline $\begin{array}{l}\text { Predict Variables } \\
\quad \text { entrepreneurial idiosyncrasy }\end{array}$ & $.270^{* * *}$ & $.488 * * *$ \\
\hline Recourses available & $.071^{* * *}$ & -.120 \\
\hline level of experience & $.097^{* * *}$ & .284 \\
\hline \multicolumn{3}{|l|}{ Control Variables } \\
\hline gender & 141 & -.038 \\
\hline bellow bachelor's degree & .161 & -.088 \\
\hline above bachelor’s degre & $.221 *$ & -.126 \\
\hline leading role & .139 & .070 \\
\hline Enterprises formed & .125 & .111 \\
\hline Growth Space & .150 & .014 \\
\hline Self-realization needs & 124 & -.062 \\
\hline Strong Commitment & 141 & -.065 \\
\hline 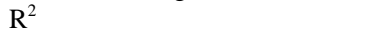 & .812 & .525 \\
\hline Adj-R ${ }^{2}$ & .777 & .435 \\
\hline df & 69 & 69 \\
\hline $\mathrm{F}$ & 22.825 & 5.833 \\
\hline
\end{tabular}

Significant test of Regression correlations of M1 shows that there are positive correlations between entrepreneurial idiosyncrasies, education background, Recourses available and level of experience with knowledge results. Significant test of Regression correlations of M2 shows positive correlations between entrepreneurial idiosyncrasies and experiencing degree, but no significant correlations between Recourses available and level of experience with experiencing degree. Than $\mathrm{H} 1$ and $\mathrm{H} 2$ are confirmed.

\section{CONCLUSIONS}

This study tries to recover the specific EL process in perspective of business model construction. Based on the theory of business model, EL process can be dived into three phase of value proposition, transactional institution construction and strategic planning. Each of the phases has different leading modes for EL. Theatrical analyzing and case study show that, the leading modes of value proposition, transactional institution construction and strategic planning are respectively observation \& innovation, contextual negotiation \& learn by doing, and Profound cognition \& Innovation. Empirical test confirmed the positive correlation between entrepreneurial idiosyncrasies which consisting of identification as entrepreneurs, social network building ability and creative thinking habits, with knowledge results and experiencing degree of EL in business model construction.

\section{REFERENCES}

[1] [1]Minnit,M.\&Bygrave,W. A dynamic model of entrepreneurial learning[J].Entrepreneurship Theory and Practice,2001,25(3):5-16.

[2] [2]Corbett,A.C. Experiential learning within the process of opportunity identification and exploitation[J].Entrepreneurship Theory and Practice,2005,29(4):473-491.

[3] [3] Catherine L. Wang and Harveen Chugh. Entrepreneurial Learning: Past Research and Future Challenges[J]. International Journal of Management Reviews, 2014,16(3):24-61

[4] [4] Kolb,D.A. Experiential Learning: Experience as the Source of Learning and Development[M]. Englewood Cliffs, NJ: Prentice Hall, 1984 
[5] [5] Lumpkin,G.T. and Lichtenstein, B.B. The role of entrepreneurial learning in the opportunity-recognition process[J]. Entrepreneurship Theory and Practice, 2005,29(4) : 451-472.

[6] [6] Politis,D. The process of entrepreneurial learning: a conceptual framework[J]. Entrepreneurship Theory and Practice, 2005, 29(4):399-424.

[7] [7]March,J.G. Exploration and exploitation in organizational learning[J]. Organization Science,1991,2:71-87.

[8] [8]Holcomb,T.R., Ireland, R.D., Holmes, R.M., Jr and Hitt, M.A. Architecture of entrepreneurial learning: exploring the link among heuristics,knowledge, and action[J]. Entrepreneurship Theory and Practice,2009,33:167-192.

[9] [9]Cope,J. Toward a dynamic learning perspective of entrepreneurship[J]. Entrepreneurship Theory and Practice,2005,29(4): 373-397.

[10] [10] Politis,D. The process of entrepreneurial learning: a conceptual framework[J]. Entrepreneurship Theory and Practice,2005,29(4): 399-424.
[11] [11] Luke Pittaway and Richard Thorpe. A framework for entrepreneurial learning: A tribute to Jason Cope[J]. Entrepreneurship \& Regional Development 2012, 24 (4): 837-859

[12] [12] Rae,D. Entrepreneurial learning: a conceptual framework for technology-based enterprise[J]. Technology Analysis \& Strategic Management,2006, 18(3):39-56.

[13] [12] Donald W. Mitchell and Carol Bruckner Coles. Business model innovation breakthrough moves[J]. journal of business strategy, 2004,25(1):16-26.

[14] [13] Daniel Veit, Eric Clemons and Alexander Benlian. Business Models An Information Systems Research Agenda[J]. Business \& Information Systems Engineering,2014(1):45-53.

[15] [14] Alexander Osterwalder and Yves Pigneur. Business Model Generation [M]. Beijing: China machine press, 2011.

[16] [15] Wei Wei , Wuxiang Zhu, and Guiping Lin. Business model theory based on the transactional structure of stakeholders [J]. Management world, 2012(12) : 125-131. 